\title{
Zhihengliuella alba sp. nov., and emended description of the genus Zhihengliuella
}

\author{
Shu-Kun Tang, ${ }^{1}$ Yun Wang, ${ }^{1,2}$ Yun Chen, ${ }^{1}$ Kai Lou, ${ }^{2}$ Lan-Lan Cao, ${ }^{1,2}$ \\ Li-Hua $\mathrm{Xu}^{1}$ and Wen-Jun $\mathrm{Li}^{1}$
}

Correspondence

Wen-Jun Li

wjli@ynu.edu.cn or

liact@hotmail.com

\author{
${ }^{1}$ The Key Laboratory for Microbial Resources of the Ministry of Education, and Laboratory for \\ Conservation and Utilization of Bio-Resources, Yunnan Institute of Microbiology, Yunnan \\ University, Kunming 650091, PR China \\ ${ }^{2}$ Xinjiang Institute of Microbiology, Xinjiang Academy of Agricultural Science, Urumqi, Xinjiang \\ 830091, PR China
}

The genus Zhihengliuella was first established by Zhang et al. (2007) and initially contained only one species, Zhihengliuella halotolerans (type strain YIM $70185^{\mathrm{T}}$ ), which was isolated from Qinghai province, north-west China. The genus Zhihengliuella is described as comprising a Grampositive, non-motile, short-rod actinobacterium that was catalase-positive and oxidase-negative. The peptidoglycan type was A4 $\alpha$, L-Lys-L-Ala-L-Glu. Cell-wall sugars contained tyvelose and glucose. The predominant menaquinones were MK-9 and MK-10 and the major fatty acids

Abbreviations: OPA, o-phthalaldehyde; PMP, 1-phenyl-3-methyl-5pyrazolone.

The GenBank/EMBL/DDBJ accession number for the $16 \mathrm{~S}$ rRNA gene sequence of strain YIM $90734^{\top}$ is EU847536.

Chromatograms of OPA- and PMP-derivatization samples and a table showing the cell-wall suger compositions of strain YIM $90734^{\top}$ and Zhihengliuella halotolerans Yim $70185^{\top}$ are available as supplementary material with the online version of this paper. were anteiso- $\mathrm{C}_{15: 0}$ and iso- $\mathrm{C}_{15: 0}$. The major polar lipids were phosphatidylglycerol, diphosphatidylglycerol and phosphatidylinositol. The $\mathrm{G}+\mathrm{C}$ content of the genomic DNA was about $66.5 \mathrm{~mol} \%$ (Zhang et al., 2007). In this paper, we describe the characterization and classification of a halotolerant actinobacterium, designated YIM $90734^{\mathrm{T}}$, which was isolated from a saline sample collected from Ganjiahu Suosuo Forest National Nature Reserve in Xinjiang province, north-west China and was considered to represent a novel species of the genus Zhihengliuella.

Strain YIM $90734^{\mathrm{T}}$ was isolated from a saline soil sample after 3 weeks incubation at $37{ }^{\circ} \mathrm{C}$ on modified ISP 5 medium comprising $\left(1^{-1}\right.$ distilled water, final $\mathrm{pH}$ 7.5): $1 \mathrm{~g}$ L-asparagine, $10 \mathrm{~g}$ glycerol, $5 \mathrm{~g}$ yeast extract, $1 \mathrm{~g} \mathrm{~K}_{2} \mathrm{HPO}_{4}$, $5 \mathrm{~g} \mathrm{KNO}_{3}, 100 \mathrm{~g} \mathrm{NaCl}$ and $15 \mathrm{~g}$ agar. $\mathrm{NaCl}$ was sterilized separately before being added to the medium. The resulting white colony was transferred twice on the same medium to purify the isolate. The strain was maintained on modified ISP 5 agar slants containing $5 \% \mathrm{NaCl}(\mathrm{w} / \mathrm{v})$ at $4{ }^{\circ} \mathrm{C}$ and as 
glycerol suspensions $(20 \%, \mathrm{v} / \mathrm{v})$ at $-20{ }^{\circ} \mathrm{C}$. Biomass for chemical and molecular studies was obtained by cultivation in shaken flasks (about 150 r.p.m.) using modified ISP 5 medium [5\%(w/v) NaCl, pH 7.5] at $37{ }^{\circ} \mathrm{C}$ for 1 week.

Cell morphology was determined for cultures grown for 6 , 12, 24 and $48 \mathrm{~h}$ on modified ISP 5 agar medium supplemented with $5 \%(\mathrm{w} / \mathrm{v}) \mathrm{NaCl}$ at $37^{\circ} \mathrm{C}$. Cell morphology was examined by using transmission electron microscopy with a model $\mathrm{H}-800$ transmission electron microscope (Hitachi). Gram staining was carried out by using the standard Gram reaction and was confirmed by using the $\mathrm{KOH}$ lysis test method (Cerny, 1978). Cell motility was confirmed by the presence of turbidity throughout the tube, including semisolid medium (Leifson, 1960). The temperature range for growth was determined by incubating cells for 7 days on modified ISP 5 medium at the following temperatures: $0,4,10,15,20$, 28, 37, 45, 50 and $55{ }^{\circ} \mathrm{C}$. For $\mathrm{NaCl}$ tolerance experiments, modified ISP 5 medium was used as the basal medium and the following $\mathrm{NaCl}$ concentrations (w/v) were used: $0,1,3$, $5,10,15,20,25$ and $30 \%$. The $\mathrm{pH}$ range for growth was investigated between $4.0-10.0$ at intervals of $1 \mathrm{pH}$ unit, using the buffer system: $\mathrm{pH}$ 4.0-5.0: $0.1 \mathrm{M}$ citric acid/ $0.1 \mathrm{M}$ sodium citrate; $\mathrm{pH}$ 6.0-8.0: $0.1 \mathrm{M} \mathrm{KH}_{2} \mathrm{PO}_{4} / 0.1 \mathrm{M}$ $\mathrm{NaOH}$; and pH 9.0-10.0: 0.1 M NaHCO$/ 0.1 \mathrm{M} \mathrm{Na}_{2} \mathrm{CO}_{3}$. Catalase activity was determined by production of bubbles after the addition of a drop of $3 \% \mathrm{H}_{2} \mathrm{O}_{2}$. Oxidase activity was determined by using oxidation of tetramethyl- $p$ phenylenediamine. Hydrolysis of casein, starch and Tweens 20, 40 and 80 was determined as described by Cowan \& Steel (1965). Enzyme activities and acid production from carbohydrates were determined by using the API ZYM and API 50CHB system (bioMérieux), according to the manufacturer's instructions. Utilization of organic substrates was tested using Biolog GP2 microplates of the Microlog system (Biolog; 95 substrates). Strains were suspended in pre-warmed sterile saline medium (5\% $\mathrm{NaCl}$ ), within the density range specified by the manufacturer. The API 50CHB, API ZYM and Biolog GP2 tests were performed in duplicate.

Cells of strain YIM $90734^{\mathrm{T}}$ were Gram-positive, nonmotile, short rods and formed white colonies. No spores were observed. Growth occurred at $4-45{ }^{\circ} \mathrm{C}$, with optimum growth at $28-37{ }^{\circ} \mathrm{C}$. The optimum $\mathrm{NaCl}$ concentration for growth was $5 \%$. Growth was very slow at pH 5.0 and $\mathrm{pH}$ 9.0. The detailed physiological and biochemical properties of strain YIM $90734^{\mathrm{T}}$ are given in Table 1 and in the species description.

A purified cell-wall preparation was obtained and hydrolysed as described by Schleifer \& Kandler (1972). Z . halotolerans YIM $70185^{\mathrm{T}}$ was used as a reference strain for analysis of the cell-wall amino acids and sugars. Amino acids in cell-wall hydrolysates were analysed by using precolumn derivatization with $o$-phthalaldehyde (OPA) by using HPLC (Agilent 1100). Ten amino acid standards (10 $\mu \mathrm{l}, 0.2 \mathrm{mM}$; Sigma) and $10 \mu \mathrm{l}$ hydrolysed purified cell wall of strain YIM $90734^{\mathrm{T}}$ were dissolved in $30 \mu \mathrm{l} 0.1 \mathrm{M}$ borax buffer and $10 \mu \mathrm{l}$ OPA (Agilent Technologies) was added and allowed to react for $50 \mathrm{~s}$ at room temperature. Analysis of the precolumn derivatization of amino acids with OPA was carried out using the Agilent 1100 HPLC system, equipped with an Agilent four-unit pump, a 7125 injector, G1314A UV detector and a column oven (ABI). The analytical column used was a ZORBAX Eclipse-AAA $(4.6 \times 150 \mathrm{~mm}, 3.5 \mu \mathrm{m}$; Agilent). The wavelength used for UV detection was $338 \mathrm{~nm}$. Elution was carried out at a flow rate of $1.0 \mathrm{ml} \mathrm{min}^{-1}$ at $40{ }^{\circ} \mathrm{C}$. The mobile phase A contained $\mathrm{CH}_{3} \mathrm{COONa}$ at $0.05 \mathrm{~mol} \mathrm{l}^{-1}$ and $0.3 \%$ tetrahydrofuran, and phase $\mathrm{B}$ was acetonitrile/methanol $(1: 1$, by vol.), by using gradient elution of $0-50-50 \%$ buffer $B$ with a linear increase from 0 to 25 to $30 \mathrm{~min}$. Cell-wall sugars were detected by using precolumn derivatization with 1-phenyl-3-methyl-5-pyrazolone (PMP) by HPLC (Agilent 1100). Seven monosaccharide standards $(80 \mu \mathrm{l}$, $1.0 \mathrm{mM}$; Sigma) or $80 \mu \mathrm{l}$ hydrolysed purified cell-wall of strain YIM $90734^{\mathrm{T}}$ and $80 \mu \mathrm{l} 0.25 \mathrm{M}$ methanol solution of PMP and $80 \mu \mathrm{l} 0.2 \mathrm{M} \mathrm{NaOH}$ were mixed. Each mixture was allowed to react for $30 \mathrm{~min}$ at $70{ }^{\circ} \mathrm{C}$, cooled to room temperature and neutralized with $80 \mu \mathrm{l} 0.2 \mathrm{M} \mathrm{HCl}$ to $\mathrm{pH} 7.0$, and extracted with isoamyl acetate. After vigorous shaking and centrifugation, the organic phase was carefully discarded to remove the excess reagents. The extraction process was repeated three times, using chloroform instead of isoamyl acetate for the third process; the aqueous layer was then collected and $10 \mu \mathrm{l}$ was taken for HPLC analysis. The analytical column used was a ZORBAX Eclipse XDBC18 $(4 \times 250 \mathrm{~mm}, 5 \mu \mathrm{m}$; Agilent). The wavelength used for UV detection was $250 \mathrm{~nm}$. Elution was carried out at a flow rate of $1.0 \mathrm{ml} \mathrm{min}^{-1}$ at $40{ }^{\circ} \mathrm{C}$ for $30 \mathrm{~min}$. Mobile phase $\mathrm{A}$ was acetonitrile, and phase $\mathrm{B}$ was $0.05 \mathrm{M}$ sodium acetate $\left(\mathrm{KH}_{2} \mathrm{PO}_{4}-\mathrm{NaOH}, \mathrm{pH} 6.9\right)$, phase $\mathrm{A}: \mathrm{B}=17: 83$ $(\mathrm{v} / \mathrm{v})$. Fatty acids were analysed as described by Sasser (1990) using the Microbial Identification System (MIDI). Menaquinones were extracted and purified as described by Komagata \& Suzuki (1987). The purified menaquinones were dissolved in acetone and separated by using HPLC (Kroppenstedt, 1982). Polar lipids were extracted, examined by two-dimensional TLC and identified using published procedures (Minnikin et al., 1984).

Strain YIM $90734^{\mathrm{T}}$ contained Lys, Ala and Glu by HPLC (see Supplementary Fig. S1, available in IJSEM Online), which is characteristic of the genus Zhihengliuella (peptidoglycan type A4 $\alpha$, L-Lys-L-Ala-L-Glu; Zhang et al., 2007). Major cell wall sugars contained tyvelose and mannose; minor amounts of glucose, galactose and rhamnose were also detected (Supplementary Fig. S2, in IJSEM Online), similar to Z. halotolerans YIM $70185^{\mathrm{T}}$. Tyvelose was the characteristic sugar of the genus Zhihengliuella, but was not found in the genera Kocuria, Nesterenkonia, Arthrobacter and Micrococcus of the family Micrococcineae (Zhang et al., 2007). Detailed cell-wall sugars, phospholipids, menaquinones and the cellular fatty acid profile are given in Tables 1 and 2 and in the species description. 
Table 1. Differential phenotypic characteristics of strain YIM $90734^{\top}$ (Z. alba sp. nov.) and Z. halotolerans YIM $70185^{\top}$

Strains: 1, 2. alba YIM $90734^{\mathrm{T}} ; 2$, 2. halotolerans YIM $70185^{\mathrm{T}}$.

Both strains are Gram-positive, short rods, non-motile, halotolerant, catalase-positive and oxidase-negative actinobacteria. Both strains are positive for esterase (C4), esterase lipase (C8), $\alpha$-glucosidase, and hydrolysis of aesculin, gelatin and Tweens 40 and 80 . Both strains produce acid from erythritol, D-ribose, D-lactose, D-xylose, maltose, Dfructose, amygdalin, starch, L-sorbose, L-rhamnose and D-mannitol, and can utilize the following substrates as sole carbon or nitrogen and energy sources: dextrin, mannan, Tween 40 , Tween 80 , D-fructose, $\alpha$-D-glucose, myo-inositol, maltose, D-mannose, methyl $\alpha$-D-glucoside, palatinose, Darabitol, D-psicose, sucrose, D-tagatose, trehalose, $\alpha$-ketovaleric acid and thymidine. Both strains are negative for nitrate reduction, $\mathrm{H}_{2} \mathrm{~S}$ production, methyl red and Voges-Proskauer test, $\alpha$-galactosidase, $\beta$ glucuronidase, $N$-acetyl- $\beta$-glucosaminidase, $\alpha$-mannosidase, $\alpha$-fucosidase, and hydrolysis of urea, cellulose, casein and chitin. Both strains do not produce acid from D-arabinose, D-galactose, melezitose, D-mannose, dulcitol, cellobiose, methyl $\alpha$-D-mannopyranoside, methyl $\alpha$-D-glucopyranoside, $N$-acetylglucosamine, melibiose, trehalose, inulin, D-lyxose, D-tagatose, D-fucose, L-fucose, L-arabitol, potassium gluconate or potassium 2-ketogluconate, and do not utilize the following substrates as sole carbon or nitrogen and energy sources: $\alpha$-cyclodextrin, glycogen, inulin, $N$-acetyl-D-glucosamine, amygdalin, arbutin, L-fucose, D-galacturonic acid, D-gluconic acid, lactulose, melezitose, methyl $\alpha$-Dgalactoside, 3-methyl-D-glucose, $\rho$-hydroxy-phenylacetic acid, lactamide, D-lactic acid methyl ester, L-lactic acid, succinic acid, $\mathrm{N}$-acetyl-Lglutamic acid, L-alaninamide, L-alanine, glycyl L-glutamic acid, Lpyroglutamic acid, putrescine and adenosine. + , Positive; - , negative.

\begin{tabular}{|lcc|}
\hline Characteristic & $\mathbf{1}$ & $\mathbf{2}^{*}$ \\
\hline Pigmentation & White & Pale yellow \\
NaCl range for growth $(\%, \mathrm{w} / \mathrm{v})$ & $0-15$ & $0-25^{\star}$ \\
Optimal NaCl concentration $(\%, \mathrm{w} / \mathrm{v})$ & 5 & $10^{*}$ \\
pH range for growth & $5-9$ & $6-10^{*}$ \\
Optimum pH range & $6-8$ & $8-9^{*}$ \\
Hydrolysis of: & & \\
Starch & - & + \\
Tween 20 & - & + \\
Utilization of (Biolog GP2): & & \\
$\beta$-Cyclodextrin & - & + \\
$N$-Acetyl-D-galactosamine & + & - \\
L-Arabinose & - & + \\
Cellobiose & + & - \\
Gentiobiose & - & + \\
$\alpha$-D-Lactose & + & - \\
Maltotriose & - & + \\
Melibiose & - & + \\
Methyl $\beta$-D-galactoside & - & + \\
Methyl $\beta$-D-glucoside & - & + \\
Methyl $\alpha$-D-mannoside & - & + \\
Salicin & - & + \\
Sedoheptulosan & - & + \\
D-Sorbitol & - & + \\
Stachyose & - & + \\
Turanose & - & + \\
Acetic acid & & + \\
$\alpha$-Hydroxybutyric acid & & + \\
& - & + \\
\hline
\end{tabular}

Table 1. cont.

\begin{tabular}{|c|c|c|}
\hline Characteristic & 1 & $2^{*}$ \\
\hline$\beta$-Hydroxybutyric acid & - & + \\
\hline$\gamma$-Hydroxybutyric acid & - & + \\
\hline$\alpha$-Ketoglutaric acid & - & + \\
\hline D-Malic acid & - & + \\
\hline L-Malic acid & - & + \\
\hline Pyruvic acid methyl ester & - & + \\
\hline Pyruvic acid & - & + \\
\hline Succinamic acid & - & + \\
\hline D-Alanine & - & + \\
\hline L-Alanyl glycine & - & + \\
\hline L-Asparagine & + & - \\
\hline L-Glutamic acid & - & + \\
\hline L-Serine & + & - \\
\hline 2,3-Butanediol & - & + \\
\hline $2^{\prime}$-Deoxyadenosine & + & - \\
\hline Inosine & - & + \\
\hline Uridine & - & + \\
\hline Thymidine- $5^{\prime}$-monophosphate & - & + \\
\hline Uridine- $5^{\prime}$-monophosphate & - & + \\
\hline D-Fructose 6-phosphate & - & + \\
\hline$\alpha$-D-Glucose 1-phosphate & - & + \\
\hline D-Glucose 6-phosphate & - & + \\
\hline DL- $\alpha$-Glycerol phosphate & - & + \\
\hline \multicolumn{3}{|l|}{ Enzymic properties (API ZYM): } \\
\hline Alkaline phosphatase & - & + \\
\hline Lipase $(\mathrm{C} 14)$ & - & + \\
\hline Leucine arylamidase & + & - \\
\hline Valine arylamidase & + & - \\
\hline Cystine arylamidase & + & - \\
\hline Trypsin & + & - \\
\hline$\alpha$-Chymotrypsin & + & - \\
\hline Acid phosphatase & + & - \\
\hline Naphthol-AS-BI-phosphohydrolase & + & - \\
\hline$\beta$-Galactosidase & + & - \\
\hline$\beta$-Glucosidase & + & - \\
\hline \multicolumn{3}{|l|}{ Acid production from (API 50CHB): } \\
\hline L-Arabinose & - & + \\
\hline Glycerol & - & + \\
\hline L-Xylose & + & - \\
\hline D-Adonitol & - & + \\
\hline D-Sorbitol & - & + \\
\hline Methyl $\beta$-D-xylopyranoside & - & + \\
\hline D-Glucose & + & - \\
\hline Inositol & - & + \\
\hline Arbutin & - & + \\
\hline Aesculin & - & + \\
\hline Salicin & - & + \\
\hline Sucrose & + & - \\
\hline Raffinose & - & + \\
\hline Turanose & - & + \\
\hline Glycogen & - & + \\
\hline Xylitol & - & + \\
\hline Gentiobiose & - & + \\
\hline D-Arabitol & - & + \\
\hline Potassium 5-ketogluconate & - & + \\
\hline DNA G $+\mathrm{C}$ content $(\mathrm{mol} \%)$ & 70.3 & $66.5^{*}$ \\
\hline
\end{tabular}

${ }^{\star}$ Data for strain Z. halotolerans YIM $70185^{\mathrm{T}}$ were from Zhang et al. (2007). Other data were from this study. 
Table 2. Cellular fatty acid compositions of strain YIM $90734^{\top}$ (Z. alba sp. nov.) and Z. halotolerans YIM $70185^{\top}$

Values are percentages of total fatty acids. - , Not detected or $<0.1 \%$. Data for strain Z. halotolerans YIM $70185^{\mathrm{T}}$ were from Zhang et al. (2007).

\begin{tabular}{|lcc|}
\hline Fatty acid & YIM $^{\text {90734 }}{ }^{\mathbf{T}}$ & YIM $^{\text {70185 }}{ }^{\mathbf{T}}$ \\
\hline Straight-chain & & \\
$\mathrm{C}_{14: 0}$ & 0.9 & 0.8 \\
$\mathrm{C}_{15: 0}$ & - & 0.2 \\
$\mathrm{C}_{16: 0}$ & 1.3 & 2.5 \\
$\mathrm{C}_{18: 0}$ & 0.4 & - \\
Branched & & \\
iso- $\mathrm{C}_{14: 0}$ & 0.9 & 0.8 \\
iso- $\mathrm{C}_{15: 0}$ & 5.4 & 15.0 \\
anteiso- $\mathrm{C}_{15: 0}$ & 61.3 & 63.9 \\
anteiso- $\mathrm{C}_{15: 1}$ & 0.5 & 0.2 \\
iso- $\mathrm{C}_{16: 0}$ & 6.8 & 7.1 \\
iso- $\mathrm{C}_{17: 0}$ & 0.9 & 1.0 \\
anteiso- $\mathrm{C}_{17: 0}$ & 15.1 & 8.5 \\
\hline
\end{tabular}

Extraction of genomic DNA and PCR amplification of the 16S rRNA gene were performed as described by Li et al. (2007). The sequence obtained was compared with available 16S rRNA gene sequences from GenBank using the program BLAST to determine an approximate phylogenetic affiliation, and the sequences were aligned with those of closely related species by using the CLUSTAL_X (Thompson et al., 1997) program. Phylogenetic analyses were performed using three tree-making algorithms, neighbour-joining (Saitou \& Nei, 1987), maximumlikelihood (Felsenstein, 1981) and maximum-parsimony (Fitch, 1971). A phylogenetic tree was constructed using the neighbour-joining method of Saitou \& Nei (1987) from $K_{\text {nuc }}$ values (Kimura, 1980), using MEGA version 4.0 (Tamura et al., 2007). The topology of the phylogenetic tree was evaluated by using the bootstrap resampling method with 1000 replicates (Felsenstein, 1985).

The almost-complete 16S rRNA gene sequence of strain YIM $90734^{\mathrm{T}}$ determined in this study comprised 1454 nucleotides. Comparative $16 \mathrm{~S}$ rRNA gene sequence analysis showed that, phylogenetically, strain YIM $90734^{\mathrm{T}}$ was related most closely to members of the family Micrococcineae (Fig. 1). In the phylogenetic tree based on the neighbour-joining algorithm, strain YIM $90734^{\mathrm{T}}$

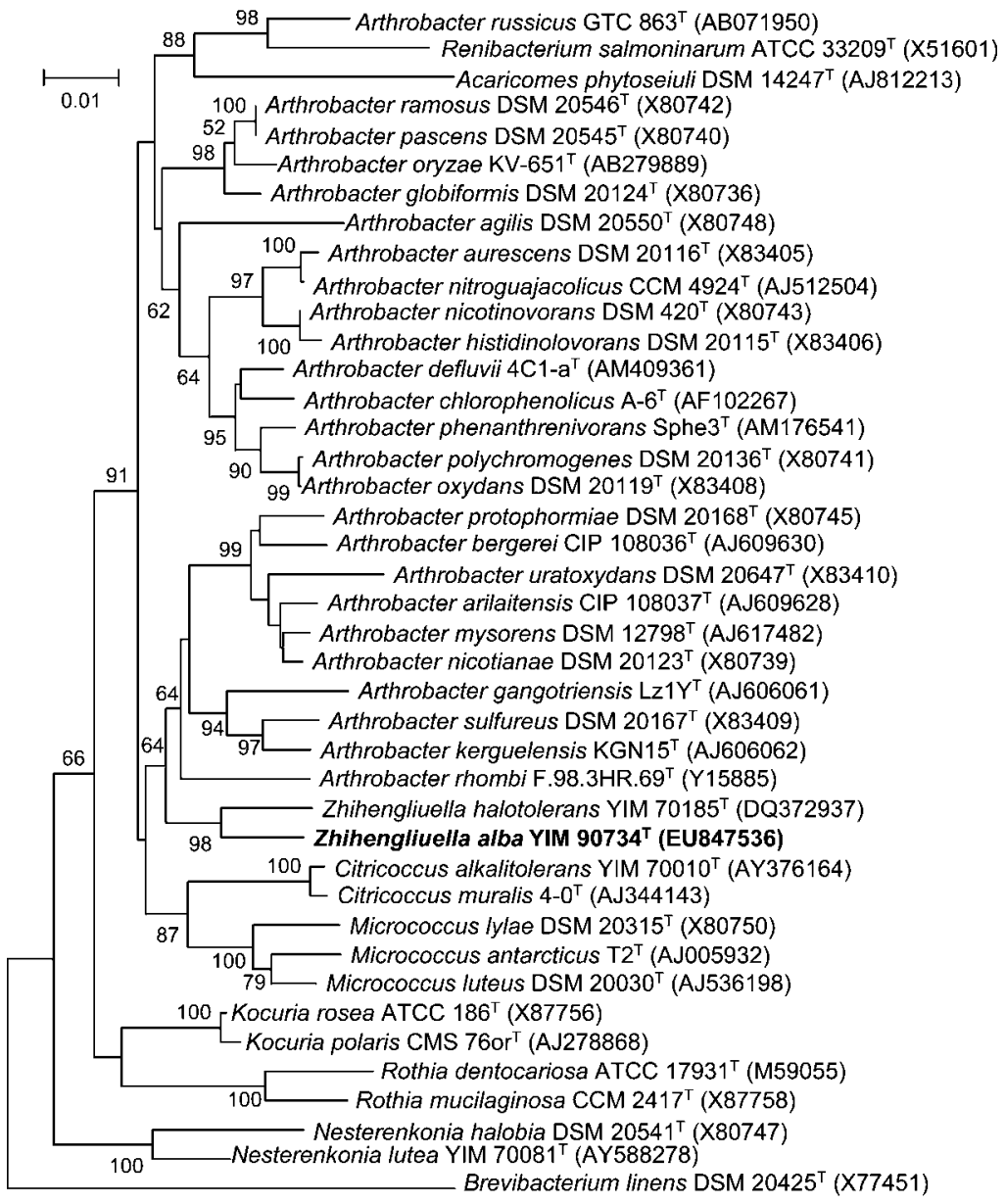

Fig. 1. Phylogenetic tree based on $16 \mathrm{~S}$ rRNA gene sequence constructed by using the neighbour-joining method showing the interrelationships of strain YIM $90734^{\top}$ and closely related recognized species. Numbers at branch points are bootstrap percentages (1000 resamplings; only values above $50 \%$ are shown). The sequence of Brevibacterium linens DSM $20425^{\top}$ (X77451) was used as an outgroup. Bar, $1 \%$ sequence divergence. 
clustered with the type strain of $Z$. halotolerans. This relationship was supported by all tree-making methods used in this study (data not shown). The 16S rRNA gene sequence similarity between strain YIM $90734^{\mathrm{T}}$ and $Z$. halotolerans was $97.7 \%$. Levels of $16 \mathrm{~S}$ rRNA gene sequence similarity of 96.1-96.6\% were shown between strain YIM $90734^{\mathrm{T}}$ and the type strains of six recognized Arthrobacter species; Arthrobacter rhombi (96.6\%), Arthrobacter pascens (96.5\%), Arthrobacter ramosus (96.5\%), Arthrobacter oryzae (96.4\%), Arthrobacter chlorophenolicus (96.2\%) and Arthrobacter phenanthrenivorans (96.1\%).

The genomic $\mathrm{G}+\mathrm{C}$ content was determined by using the method of Mesbah et al. (1989) with DNA from Escherichia coli K-12 as a control. The DNA of strain Yim $90734^{\mathrm{T}}$ was hydrolysed and the resultant nucleotides were analysed by using reversed-phase HPLC. DNA-DNA hybridization was performed fluorometrically by using the methods of Ezaki et al. (1989) and He et al. (2005) with photobiotin-labelled DNA probes in microdilution wells. Hybridization was performed with five replications for each sample and the highest and lowest values in each sample were excluded. The DNA-DNA relatedness values were expressed as the mean of the remaining three values. The level of DNADNA relatedness between strain YIM $90734^{\mathrm{T}}$ and $Z$. halotolerans YIM $70185^{\mathrm{T}}$ was $41.4 \%$, a value that was well below the $70 \%$ cut-off point recommended for assignment of strains to the same genomic species (Wayne et al., 1987). The genomic $\mathrm{G}+\mathrm{C}$ content of the DNA of strain YIM $90734^{\mathrm{T}}$ was $70.3 \mathrm{~mol} \%$.

The chemotaxonomic properties of strain YIM $90734^{\mathrm{T}}$ [A4 $\alpha$, L-Lys-L-Ala-L-Glu as the peptidoglycan type; tyvelose as the major cell-wall sugar; MK-10 (64.0\%) and MK-9 $(32.7 \%)$ as predominant menaquinones; diphosphatidylglycerol, phosphatidylglycerol, phosphatidylinositol, one unknown phospholipid and two unknown glycolipids as the polar lipids] were different from those of members of the genus Arthrobacter (A3 $\alpha$ as peptidoglycan type; MK$9\left(\mathrm{H}_{2}\right)$ as predominant menaquinone; no tyvelose in the cell-wall sugar), indicating the affiliation of this new isolate to the genus Zhihengliuella (Zhang et al., 2007). The results of the $16 \mathrm{~S}$ rRNA gene sequence analysis also supported the close affiliation of strain YIM $90734^{\mathrm{T}}$ with the genus Zhihengliuella, which was confirmed by the high bootstrap resampling value $(98 \%)$, and formed a monophyletic branch at the periphery of the evolutionary radiation occupied by the genus Arthrobacter. Therefore, the chemotaxonomic and phylogenetic results clearly indicate that strain YIM $90734^{\mathrm{T}}$ belonged to the genus Zhihengliuella. However, strain YIM $90734^{\mathrm{T}}$ could be differentiated from $Z$. halotolerans YIM $70185^{\mathrm{T}}$ by some morphological, physiological and chemotaxonomic properties (Tables 1 and 2 and Supplementary Table S1), i.e. colonies of strain YIM $90734^{\mathrm{T}}$ are white, and growth does not occur in $25 \% \mathrm{NaCl}$, whereas colonies of $Z$. halotolerans YIM $70185^{\mathrm{T}}$ were pale yellow and growth occurred with up to $25 \% \mathrm{NaCl}$. In addition, strain YIM $90734^{\mathrm{T}}$ and $Z$. halotolerans YIM $70185^{\mathrm{T}}$ could be differentiated by means of hydrolysis of starch and Tween 20, acid production from carbohydrates, enzyme properties and utilization of sole carbon or nitrogen energy sources, as shown in Table 1. Furthermore, strain YIM $90734^{\mathrm{T}}$ exhibited some differences with $Z$. halotolerans YIM $70185^{\mathrm{T}}$ in their fatty acid compositions. For instance, anteiso- $\mathrm{C}_{15: 0}(61.3 \%)$ and anteiso- $\mathrm{C}_{17: 0}(15.1 \%)$ were the major fatty acids of strain YIM $90734^{\mathrm{T}}$, whereas the major fatty acids of $Z$. halotolerans YIM $70185^{\mathrm{T}}$ were anteiso- $\mathrm{C}_{15: 0}(63.9 \%)$ and iso- $\mathrm{C}_{15: 0}(15.0 \%)$. Therefore, on the basis of the phenotypic and genotypic distinctiveness and levels of DNADNA hybridization, strain YIM $90734^{\mathrm{T}}$ should be placed in the genus Zhihengliuella as representing a novel species, for which the name Zhihengliuella alba sp. nov. is proposed. As a consequence of the newly reported characteristics, the description of the genus Zhihengliuella (Zhang et al., 2007) has been emended.

\section{Emended description of the genus Zhihengliuella Zhang et al. 2007}

The description of the genus is as given previously (Zhang et al., 2007), but with the following amendments. Diagnostic cell-wall sugars are tyvelose and mannose. Major fatty acids are anteiso- $\mathrm{C}_{15: 0}$ and iso- $\mathrm{C}_{15: 0}$ or anteiso- $\mathrm{C}_{15: 0}$ and anteiso- $\mathrm{C}_{17: 0}$. The $\mathrm{G}+\mathrm{C}$ content of the genomic DNA is $66-70.3 \mathrm{~mol} \%$.

\section{Description of Zhihengliuella alba sp. nov.}

Zhihengliuella alba (al'ba. L. fem. adj. alba white, referring to the white colour of colonies).

Cells are aerobic, Gram-positive, short rods, $0.5-0.9 \times 1.3-$ $1.8 \mu \mathrm{m}$ in size, non-motile and without flagella. Colonies are circular, smooth and white on modified ISP 5 medium. Growth occurs in $0-15 \%(\mathrm{w} / \mathrm{v}) \mathrm{NaCl}$, with good growth at $5 \%(\mathrm{w} / \mathrm{v}) \mathrm{NaCl}$. Growth occurs at $4-45^{\circ} \mathrm{C}$ and $\mathrm{pH} 5.0$ 9.0, with optimum growth at $28-37^{\circ} \mathrm{C}$ and $\mathrm{pH}$ 6.0-8.0. Catalase-positive and oxidase-negative. Negative for milk peptonization, methyl red and Voges-Proskauer tests, $\mathrm{H}_{2} \mathrm{~S}$ production, nitrate reduction, and hydrolysis of starch, urea, cellulose, casein, chitin and Tween 20. Positive for hydrolysis of aesculin, gelatin, Tween 40 and Tween 80 . Enzyme activities (API ZYM) are observed for esterase (C4), esterase lipase (C8), leucine arylamidase, valine arylamidase, cystine arylamidase, trypsin, $\alpha$-chymotrypsin, acid phosphatase, naphthol-AS-BI-phosphohydrolase, $\beta$ galactosidase, $\alpha$-glucosidase and $\beta$-glucosidase. Negative for alkaline phosphatase, lipase (C14), $\alpha$-galactosidase, $\beta$ glucuronidase, $\quad N$-acetyl- $\beta$-glucosaminidase, $\alpha$-mannosidase and $\alpha$-fucosidase. Acid is produced (API 50CHB) from erythritol, D-ribose, DL-xylose, D-glucose, D-fructose, L-sorbose, L-rhamnose, D-mannitol, amygdalin, maltose, sucrose and starch, but not from glycerol, L-arabinose, Darabinose, D-adonitol, methyl $\beta$-D-xylopyranoside, Dgalactose, D-mannose, dulcitol, inositol, D-sorbitol, methyl $\alpha$-D-mannopyranoside, methyl $\alpha$-D-glucopyranoside, $N$ acetylglucosamine, turanose, arbutin, aesculin, cellobiose, 
salicin, D-lactose, melibiose, trehalose, inulin, melezitose, raffinose, glycogen, xylitol, gentiobiose, D-lyxose, D-tagatose, DL-fucose, DL-arabitol, potassium gluconate, potassium 2-ketogluconate and potassium 5-ketogluconate. The following substrates are utilized as sole carbon or nitrogen and energy sources (Biolog GP2): dextrin, mannan, Tweens 40 and 80, $N$-acetyl-D-galactosamine, Darabitol, cellobiose, D-fructose, D-galactose, $\alpha$-D-glucose, myo-inositol, $\alpha$-D-lactose, maltose, D-mannitol, D-mannose, methyl $\alpha$-D-glucoside, palatinose, D-psicose, raffinose, L-rhamnose, D-ribose, sucrose, D-tagatose, trehalose, xylitol, D-xylose, $\alpha$-ketovaleric acid, succinic acid monomethyl ester, propionic acid, pyruvic acid, L-asparagine, L-serine, glycerol, 2 '-deoxyadenosine and thymidine. The following substrates are not utilized: $\alpha$-cyclodextrin, $\beta$-cyclodextrin, starch, inulin, $N$-acetyl-D-glucosamine, amygdalin, L-arabinose, arbutin, L-fucose, D-galacturonic acid, gentiobiose, D-gluconic acid, lactulose, melezitose, melibiose, methyl $\alpha$ D-galactoside, methyl $\beta$-D-galactoside, 3-methyl-D-glucose, methyl $\beta$-D-glucoside, methyl $\alpha$-D-mannoside, salicin, sedoheptulosan, D-sorbitol, stachyose, turanose, acetic acid, $\alpha$-hydroxybutyric acid, $\beta$-hydroxybutyric acid, $\gamma$-hydroxybutyric acid, $\rho$-hydroxyphenylacetic acid, $\alpha$-ketoglutaric acid, lactamide, D-lactic acid methyl ester, L-lactic acid, Dmalic acid, L-malic acid, pyruvic acid methyl ester, pyruvic acid, succinamic acid, succinic acid, $N$-acetyl-L-glutamic acid, L-alaninamide, DL-alanine, L-alanyl glycine, L-glutamic acid, glycyl L-glutamic acid, L-pyroglutamic acid, putrescine, 2,3-butanediol, adenosine, inosine, uridine, adenosine- $5^{\prime}$-monophosphate, thymidine-5'-monophosphate, uridine- $5^{\prime}$-monophosphate, D-fructose 6-phosphate, $\alpha$-D-glucose 1-phosphate, D-glucose 6-phosphate and DL- $\alpha$-glycerol phosphate. Peptidoglycan type is A4 $\alpha$, LLys-L-Ala-L-Glu. Major cell sugars contain tyvelose and mannose; minor amounts of glucose, rhamnose and galactose are also detected. Predominant menaquinones are MK-10 (64.0\%) and MK-9 (32.7\%); a minor amount of MK-8 (3.3\%) is also detected. Polar lipids are diphosphatidylglycerol, phosphatidylglycerol, phosphatidylinositol, an unknown phospholipid and two unknown glycolipids. Major cellular fatty acids are anteiso- $\mathrm{C}_{15: 0}$ and anteiso- $\mathrm{C}_{17: 0}$; minor amounts of $\mathrm{C}_{14: 0}$, iso- $\mathrm{C}_{14: 0}$, iso$\mathrm{C}_{15: 0}$, anteiso- $\mathrm{C}_{15: 1}, \mathrm{C}_{16: 0}$, iso- $\mathrm{C}_{16: 0}$, iso- $\mathrm{C}_{17: 0}$ and $\mathrm{C}_{18: 0}$ are also detected. The DNA G $+\mathrm{C}$ content of the type strain is $70.3 \mathrm{~mol} \%$.

The type strain, YIM $90734^{\mathrm{T}}\left(=\right.$ KCTC $19375^{\mathrm{T}}=\mathrm{DSM}$ $21143^{\mathrm{T}}$ ), was isolated from a saline soil sample collected from Ganjiahu Suosuo Forest National Nature Reserve in Xinjiang province, north-west China.

\section{Acknowledgements}

This research was supported by the National Basic Research Program of China (no. 2004CB719601), the Key Project of Chinese Ministry of Education (no. 206139), the National Natural Science Foundation of China (nos 30600001, 30860002, 30870005), the Yunnan Provincial International cooperative Program (no. 2005GH21) and the Open Project Program of the Extremophiles Lab of Xinjiang (no. XJYS0203-
2005-01) and Youth Technological Innovation Foundation of Xinjiang Academy of Agricultural Science (no. 2007Q07). W.-J. L. was supported by the Program for New Century Excellent Talents in University.

\section{References}

Cerny, G. (1978). Studies on aminopeptidase for the distinction of Gram-negative from Gram-positive bacteria. Eur J Appl Microbiol Biotechnol 5, 113-122.

Cowan, S. T. \& Steel, K. J. (1965).. Manual for the Identification of Medical Bacteria. London: Cambridge University Press.

Ezaki, T., Hashimoto, Y. \& Yabuuchi, E. (1989). Fluorometric deoxyribonucleic acid-deoxyribonucleic acid hybridization in microdilution wells as an alternative to membrane filter hybridization in which radioisotopes are used to determine genetic relatedness among bacterial strains. Int J Syst Bacteriol 39, 224-229.

Felsenstein, J. (1981). Evolutionary trees from DNA sequences: a maximum likelihood approach. J Mol Evol 17, 368-376.

Felsenstein, J. (1985). Confidence limits on phylogenies: an approach using the bootstrap. Evolution 39, 783-791.

Fitch, W. M. (1971). Toward defining the course of evolution: minimum change for a specific tree topology. Syst Zool 20, 406-416.

He, L., Li, W., Huang, Y., Wang, L., Liu, Z., Lanoot, B., Vancanneyt, M. \& Swings, J. (2005). Streptomyces jietaisiensis sp. nov., isolated from soil in northern China. Int J Syst Evol Microbiol 55, 1939-1944.

Kimura, M. (1980). A simple method for estimating evolutionary rates of base substitutions through comparative studies of nucleotide sequence. J Mol Evol 16, 111-120.

Komagata, K. \& Suzuki, K. (1987). Lipid and cell-wall analysis in bacterial systematics. Methods Microbiol 19, 161-207.

Kroppenstedt, R. M. (1982). Separation of bacterial menaquinones by HPLC using reverse phase (RP18) and a silver loaded ion exchanger as stationary phases. J Liq Chromatogr 5, 2359-2367.

Leifson, E. (1960). Atlas of Bacterial Flagellation. London: Academic Press.

Li, W. J., Xu, P., Schumann, P., Zhang, Y. Q., Pukall, R., Xu, L. H., Stackebrandt, E. \& Jiang, C. L. (2007). Georgenia ruanii sp. nov., a novel actinobacterium isolated from forest soil in Yunnan (China) and emended description of the genus Georgenia. Int J Syst Evol Microbiol 57, 1424-1428.

Mesbah, M., Premachandran, U. \& Whitman, W. B. (1989). Precise measurement of the $\mathrm{G}+\mathrm{C}$ content of deoxyribonucleic acid by highperformance liquid chromatography. Int J Syst Bacteriol 39, 159-167.

Minnikin, D. E., O’Donnell, A. G., Goodfellow, M., Alderson, G., Athalye, M., Schaal, A. \& Parlett, J. H. (1984). An integrated procedure for the extraction of bacterial isoprenoid quinones and polar lipids. J Microbiol Methods 2, 233-241.

Saitou, N. \& Nei, M. (1987). The neighbor-joining method: a new method for reconstructing phylogenetic trees. Mol Biol Evol 4, 406-425.

Sasser, M. (1990). Identification of bacteria by gas chromatography of cellular fatty acids. USFCC Newsl 20, 16.

Schleifer, K. H. \& Kandler, O. (1972). Peptidoglycan types of bacterial cell walls and their taxonomic implications. Bacteriol Rev 36, 407-477.

Tamura, K., Dudley, J., Nei, M. \& Kumar, S. (2007). MEGA4: Molecular Evolutionary Genetics Analysis (MEGA) software version 4.0. Mol Biol Evol 24, 1596-1599.

Thompson, J. D., Gibson, T. J., Plewniak, F., Jeanmougin, F. \& Higgins, D. G. (1997). The CLUSTAL_X windows interface: flexible strategies for multiple sequence alignment aided by quality analysis tools. Nucleic Acids Res 25, 4876-4882. 
Wayne, L. G., Brenner, D. J., Colwell, R. R., Grimont, P. A. D., Kandler, O., Krichevsky, M. I., Moore, L. H., Moore, W. E. C., Murray, R. G. E. \& other authors (1987). International Committee on Systematic Bacteriology. Report of the ad hoc committee on reconciliation of approaches to bacterial systematics. Int J Syst Bacteriol 37, 463-464.
Zhang, Y. Q., Yu, L. Y., Liu, H. Y., Zhang, Y. O., Xu, L. H., Stackebrandt, E., Jiang, C. L. \& Li, W. J. (2007). Zhihengliuella halotolerans gen. nov., sp. nov. a novel member of the family Micrococcaceae from a saline soil in China. Int J Syst Evol Microbiol 57, 1018-1023. 